\title{
AGGLUTININS EXTRACTION FROM CHLORELLA VULGARIS USING THREE DIFFERENT BUFFERS
}

\author{
CAVALCANTI, V.L.R. ${ }^{1}$, NASCIMENTO, C.O. ${ }^{2}$, COSTA, R. M. P. B. ${ }^{3}$, CARVALHO, J.C.M ${ }^{2}$, \\ PORTO, A. L. F. ' , BEZERRA, R.P. ${ }^{5}$, VIANA MARQUES, D. A ${ }^{1}$. \\ ${ }^{1}$ Universidade Federal Rural de Pernambuco, Departamento de Morfologia e Fisiologia Animal \\ ${ }^{2}$ Universidade de São Paulo, Departamento de Tecnologia Bioquímico-Farmacêutica \\ E-mail para contato: daniela_viana@yahoo.com.br
}

\begin{abstract}
Agglutinins are carbohydrates applied as tools in cell biology, immunology, in the study and treatment of cancers, and in a range of areas of biochemical and biomedical research. This study aims to determine the best method of possible hemagglutinating substances extraction from Chlorella vulgaris biomass using three different buffers. The cultured was concentrated by a centrifugation at $4,000 \mathrm{xg}$ for $10 \mathrm{~min}$, lyophilized and extracted under homogenization in pure and in concentrations of $1: 5$ to $1: 20$ using the buffers $0.025 \mathrm{M}$ Tris-HCl-saline, $\mathrm{pH} 7.0 ; 0.02 \mathrm{M}$ saline-phosphate, $\mathrm{pH} 7.4$; and $0.1 \mathrm{M}$ sodium acetate, $\mathrm{pH}, 5.5$. In microtiter boards, biomass extracts were added to rabbit erythrocytes for hemagglutination activity. Positive results were obtained in Tris-HCl-saline buffer (1:10 and 1:20 dilutions) and sodium acetate buffer (pure extract and dilutions) with hemagglutination titers of $2^{12}$ $(4,096)$ at $3 \mathrm{~h}$ of homogenization. Microalgae are promising sources of useful bioactive compounds.
\end{abstract}

\section{INTRODUCTION}

Algae are very different beings in aquatic systems (or wetlands ) are mostly photosynthetic (in this case , endowed with chlorophyll a) and present vegetative structure known as the stalk, whose cell differentiation is characteristically small or zero. Thus, the term " algae " is completely devoid of taxonomic value, as designated bodies very distinct from each other as to the origin, chemical composition and morphology. Involves unicellular and multicellular organisms with planktonic and benthic habits. From these characteristics derive the terms of use set out: microalgae (microscopic algae with dimensions) and macroalgae (seaweeds with macroscopic dimensions). While benthic macroalgae are almost always (except some forms that may be floating), most microalgae have planktonic habit, although there are also many benthic and terrestrial species inhabiting humid environments (LOURENÇO, 2006). The particular location of planktonic algae are phytoplankton, or are components of photoautotrophic plankton. The various phytoplankton organisms may present as isolated cells forming colonies grouped or chained in the form of linear segments of cells. In all cases, however, little or no differentiation or specialization of the functions of the cells occurs, ie , each cell performs all life functions (GUEDES, A.C.; AMARO, H.M.; MALCATA, F.X, 2011).

The photoautotrophic marine organisms exhibit great morphological, physiological, biochemical and ecological differences, unlike what happens in the terrestrial environment, in which the various algal species have relatively similar characteristics, in this context is situated 
Chlorella vulgaris, arising from a gender unicellular green algae, Phylum Chlorophyta, spherical, about 2-10 $\mathrm{mm}$ in diameter and no flagellum . Contains the green photosynthetic pigments chlorophyll-a and - b in its chloroplast; through photosynthesis multiplies rapidly, requiring only carbon dioxide, water, sunlight, and small amounts of minerals to reproduce (GUEDES, A.C.; AMARO, H.M.; MALCATA, F.X, 2011).

The emergence and spread of searching for bioactive compounds of nutritional and/or pharmacological interest in microalgae and cyanobacteria have received great attention in scientific research. The ability of these microorganisms to synthesize numerous complex metabolites such as peptides, lipopeptides, fatty acids , carbohydrates and others has fascinated researchers to discover new molecules for employment in industries. In bioenergy, could be a cheaper and effective alternative, besides not being pollutant (GUEDES, A.C.; AMARO, H.M.; MALCATA, F.X, 2011); as bioactive compounds, especially in the pharmaceutical area, could be a healthy alternative activity against resistant bacteria to other traditional treatments (R.UMA, V. SIVASUBRAMANIAN AND S.NIRANJALI DEVARAJ., 2011), and not just for its antimicrobial activity, but also antiviral, antitumor, antioxidant and anti-inflammatory (BHAGAVATHY, S.; SUMATHI, P.; BEL, J.; S., 2011); and in the food industry, they are rich in essential nutrition compounds for the human body ( MOSTAFA, SM, 2012).

It is known that microalgae in question has a wide field of study being developed from its bioactive potential. Biotechnology of microalgae has gained considerable importance in recent decades. Applications range from simple biomass production of food and feed products to valuable ecological applications (PULZ AND WOLFG; OTTO GROSS, 2004). There are many reports on the potential and bio-economics of algal biomass to produce fuels and most of these are based on the premise that similar to terrestrial plants, these features can be used very efficiently.

Agglutinins are widely distributed in nature and have the characteristics of binding to specific carbohydrate and produce unique effects such as cell aggregation or precipitation of glycoconjugates. Agglutinins can thus serve as carbohydrates probes useful tools in cell biology, immunology, in the study and treatment of cancers, and in a range of areas of biochemical and biomedical research. In general, these proteins have similar molecular weight $(23 \mathrm{kDa}$ by gel filtration and $29 \mathrm{kDa}$ by electrophoresis on SDS polyacrylamide gel) and different isoelectric points (HORI et al., 1988). The presence of hemagglutinin has been observed in almost all living organisms, also in microalgae. Despite considerable progress in the study of distribution and biochemical haemagglutinin of seaweed algae (macroalgae), existing data are still considered insufficient to clarify its properties in vitro and its possible functions in vivo (CHU et al., 2004).

Recent research has focused on the screening of biological activities, including those with hemagglutination activity in photosynthetic microorganisms such as Microcystis aeruginosa (M228), M. viride (YAMAGUCHI et al, 1998;.. YAMAGACHI et al, 1999), Oscillatoria agardihii (SATO et al. 2000) and Chlorella pyrenoidosa (CHU et al., 2004). Hori et al. (1988) isolated three agglutinins from ethanol extracts of Solieria robusta. However, research on hemagglutinating activity from photosynthetic microorganisms, and their characterization is still scarce. For this reason, the aim of this work was to determine the best method of extraction of bioactive compounds from Chlorella vulgaris biomass using three different types of buffers. 


\section{MATERIAL AND METHODS}

\subsection{Microalgae and media}

C. vulgaris (UTEX 1803) was obtained from the UTEX (University of Texas, Austin). Cultures were maintained axenically in liquid Bold's Basal medium (BISCHOFF and BOLD, 1963) which was suggested by University of Texas Culture Collection. The culture medium was sterilized in an autoclave at $121^{\circ} \mathrm{C}$ for $20 \mathrm{~min}$.

\subsection{Culture conditions}

C. vulgaris was grown autotrophically on $400 \mathrm{~mL}$ of sterile culture media (initial $\mathrm{pH}$ of 6.8) in 1000-mL Erlenmeyer flasks at $27 \pm 1{ }^{\circ} \mathrm{C}$, under a constant fluorescent light intensity of approximately $74 \mu \mathrm{mol}$ photons $\mathrm{m}^{-2} \mathrm{~s}^{-1}$ measured by a LI-250 Light Meter with a LI-190 quantum sensor (LI-COR, USA). Agitation during cell growth was provided by sparging air. Inital cell concentration was $50 \mathrm{mg} \mathrm{L}^{-1}$ for all the cultivation conditions. Periodic samples were taken from the flasks to determine the cell density.

\subsection{Determination of cell dry weight and optical density}

Cell concentration (optical density) was estimated by absorbance of the suspension at $685 \mathrm{~nm}(\mathrm{Xu}, 2008)$ with a UV-vis spectrophotometer. A calibration curve between optical density and cell dry weight was developed by filtering the aliquots on pre-weighed GF/C filter paper. The filtered cells were dried at $105{ }^{\circ} \mathrm{C}$ until constant weight was obtained and cooled to room temperature in a desiccator before weighing. Subsequently, the culture was centrifuged at 10,000 rpm for $20 \mathrm{~min}$ at $4{ }^{\circ} \mathrm{C}$ and the dry biomass used in the compounds extraction step.

\section{$2.4 \mathrm{pH}$ determination}

$\mathrm{pH}$ was mensured using a potentiometer (METTLER TOLEDO M300) immersing the electrode in the cultures.

\subsection{Microalgae biomass extracts preparation}

Extracts biomass extracts will be prepared on the basis of Chu et al. (2006), Dinh et al. (2009) and Roman Bermejo et al. (2001) methodologies. The first consists in suspending the cells in $200 \mathrm{ml}$ of TBS buffer ( Tris-HCl - saline ) $\mathrm{pH} 7.4$ containing $25 \mathrm{mM} \mathrm{NaCl}$ at $4{ }^{\circ} \mathrm{C}$. The second method is carried out with 2 volumes of $0.02 \mathrm{M}$ phosphate buffer, $\mathrm{pH} 7.0$ containing $0.85 \% \mathrm{NaCl}$ ( saline - PBS ) at $4^{\circ} \mathrm{C}$. The third is the suspension of frozen in $1 \mathrm{M}$ sodium acetate $(\mathrm{pH} 5.5)$ buffer. In three cases, the microalgae biomass extracts were placed under stirring for 30 hours and aliquots were removed every 3 hours and centrifuged at 5,000 rpm $7 \mathrm{~min}, 4{ }^{\circ} \mathrm{C}$, using the supernatant for hemagglutinating activity with dilutions of 1:5, 1:10 and 1:20.

\subsection{Determination of hemagglutinating activity (HA)}

The determination of hemagglutinating activity (HA) in the supernatants was performed in microtiter plates, following the method described by Correia and Coelho et al. (1995). Extracts preparation $(50 \mu \mathrm{L})$ was two-fold serially diluted with $0.15 \mathrm{M} \mathrm{NaCl}$, followed by the addition of a 
$50 \mu \mathrm{L}$ suspension of rabbit erythrocytes treated with $2.5 \%(\mathrm{v} / \mathrm{v})$ glutaraldehyde. After resting for $45 \mathrm{~min}$, HA was expressed as the highest dilution exhibiting hemagglutination. Hemagglutination was observed macroscopically and judged as positive in the case that more than 50\% of erythrocytes in the well were agglutinated. Hemagglutination activity was expressed as a titer, the reciprocal of the highest two-fold dilution exhibiting positive hemagglutination. The assay was carried out in triplicate for each test solution.

\section{RESULTS AND DISCUSSION}

According to Table 1, Chlorella vulgaris biomass extracts in three buffers types used was observed hemaglutination activity. However, faster positive results were obtained in Tris-HClsaline buffer (1:10 and 1:20 dilutions) and sodium acetate buffer (pure extract and dilutions) with hemagglutination titers of $2^{12}(4,096)$ at $3 \mathrm{~h}$ of homogenization.

Table 1. Hemagglutinating activity of Chlorella vulgaris biomass extracted in three different buffers.

\begin{tabular}{lccc}
\hline Buffer type & Extracts dilutions & $\begin{array}{c}\text { Extraction time } \\
\text { of agitation } \\
\text { Overnight }(24 \mathrm{~h})\end{array}$ & $\begin{array}{c}\text { Hemagglutinating } \\
\text { activity }\end{array}$ \\
\hline Sodium phosphate & $1: 20$ & $27 \mathrm{~h}$ & $2^{7}$ \\
& Pure Extrat, $1: 5,1: 10,1: 20$ & $3 \mathrm{~h}$ & $2^{8}$ \\
Tris-HCL & $1: 10,1: 20$ & $6 \mathrm{~h}$ & $2^{12}$ \\
Sodium acetate & $1: 10,1: 20$ & $3 \mathrm{~h}$ & $2^{12}$ \\
& Pure extract, $1: 5,1: 10,1: 20$ & $6 \mathrm{~h}$ & $2^{12}$ \\
& Pure extract & $2^{12}$ \\
\hline
\end{tabular}

Some authors reported that hemagglutinins present in seaweeds have properties that facilitate rabbit erythrocytes agglutination, such as: affinity for monosaccharides, present low molecular weights and occur in monomeric forms (SAMPAIO, 1993). It can be noticed that the use of rabbit erythrocyte agglutination for analysis was also studied in this work effectively with promising results.

From the first report with seaweed by Boyd et al . (1966), the increasing number of biological applications of agglutinins has stimulated research in a large number of organisms, however, the number of these purified and characterized hemagglutinins obtained from microalgae is still considered limited.

Some authors have studied agglutinins obtaining from microalgae and some special features that may interfere with obtaining, for example, aerobic growth conditions can inhibit the production of agglutinins in Microcystis viridis (YAMAGUCHI et al., 1999) and which extracts from Microcystis aeruginosa showed hemagglutinating activity with the aid of a calcium-dependent binder (SAKAMOTO et al., 1997). The hemagglutinating activity of the present study was observed in growth natural conditions of microalgae Chlorella vulgaris and did not require dependent binders.

The same extraction buffer used in this work (Tris- $\mathrm{HCl}, \mathrm{pH} 7.0$ ) was studied by Chu et al. (2006). These authors observed hemagglutinating activity of biomass from Chlorella 
pyrenoidosa equivalent to $2^{16}$ against human type $\mathrm{B}$ erythrocytes, thereby suggesting that there is the possible presence of a non-immunological protein compound that binds to the blood, thus confirming the potential of this kind for future biotechnology studies.

\section{CONCLUSION}

Bioactive components of the extract from biomass of $C$. vulgaris showed hemagglutinating activity against rabbit erythrocytes using three different types of extraction buffers, making it a strong candidate for future applications in agglutinins research and biomedical applications.

\section{REFERENCES}

BERMEJO ROMAN R, TALAVERA EM, ALVAREZ-PEZ JM. Chromatographic purification and characterization of b-phycoerythrin from Porphyridium cruentum. Semipreparative HPLC separation and characterization of its subunits. Journal of Chromatography A, v. 917, p.135- 45, 2001.

BHAGAVATHY, S.; SUMATHI, P.; BEL, J.; S. Green algae Chlorococcumhumicola-a new source of bioactive compounds with antimicrobial activity. Asian Pacific Journal of Tropical Biomedicine, p. S1-S7, 2011.

BISCHOFF, H. W.; BOLD, H. C. Phycological Studies. IV. Some Algae from Enchanted Rock and Related Algae Species. University of Texas Publications number 6318. pp. 1-95, 1963.

BOYD,W.C.; ALMODOVAR, L.R. \& BOYD, L.G. Agglutinins in marine algae for human erythrocytes. Transfusion, 6:82-83, 1966.

CHU, C.Y.; LAIO, W.R.; HUANG, R.; LIN, L.P. Hemagglutinating and antibiotic activities of freshwater microalgae. World Journal of Microbiology and Biotechnology, v. 20, p. 817-825, 2004.

CHU, C.Y.; HUANG, R.; LIN, L.P. Purification and characterization of a novel haemagglutinin from Chlorella pyrenoidosa. Journal of Industrial Microbiology and Biotechnology, v. 33, p. 967973, 2006.

CORREIA M.T.S., COELHO L.C.B.B. Purification of a glucose/mannose specific lectin, isoform 1, from seeds of Cratylia mollis mart (Camaratu Bean), Appl Biochem Biotech. 55 (1995) 261273.

COSTA, J.A.V; RADMANN, E.M; CERQUEIRA, V.S; Perfil de ácidos graxos das microalgas Chlorella vulgaris E Chlorella minutissima cultivadas em diferentes condições. Alimentação e Nutrição, Araraquara ,v.17, n.4, p.429-436, out./dez. 2006.

DINH, H. L.; HORI, K.; QUANG, N. H. Screening and preliminary characterization of hemagglutinins in Vietnamese marine algae. Journal Applied of Phycology, v. 21, p. 89-97, 2009.

GUEDES, A.C.; AMARO, H.M.; MALCATA, F.X. Microalgae as Sources of Carotenoids. Mar. 
Drugs 2011, 9, 625-644.

HORI, K., IKEGAMI, S., MIYAZAWA, K. \& ITO, K. Mitogenic and antineoplastic isoagglutinins from the red alga Solieria robusta. Phytochemistry, v. 27(7), p. 2063-2067, 1988.

LOURENÇO, S.O. Cultivo de microalgas marinhas - princípios e aplicações. São Carlos: RiMa, 2006.

MOSTAFA,S.M. Microalgal Biotechnology: prospects and applications. Plant Science. Chaper 12, 2012. Informations are available at the site: http://dx.doi.org/10.5772/53649.

PULZ, O.; GROSS, W. Valuable products from biotechnology of microalgae. Applied Microbiology Biotechnology, v.65, p.635-648, 2004.

SAKAMOTO, T.; SHEN, G.; HIGASHI, S.; MURATA, N.; BRYANT, D. A. Alteration of lowtemperature susceptibility of the cyanobacterium Synechococcus sp. PCC 7002 by genetic manipulation of membrane lipid unsaturation. Archives of Microbiology, v.169, n. 1, p. 20-28, 1997. http://dx.doi.org/10.1007/s002030050536.

SAMPAIO, ALEXANDRE HOLANDA et al. Hemaglutininas de algas marinhas. Revista Brasileira de Fisiologia Vegetal, v. 5, p. 171-177, 1993.

SATO, YUICHIRO et al. Purification and characterization of a novel lectin from a freshwater cyanobacterium, Oscillatoria agardhii. Comparative Biochemistry and Physiology Part B: Biochemistry and Molecular Biology, v. 125, n. 2, p. 169-177, 2000.

UMA R., SIVASUBRAMANIAN V., S.NIRANJALI DEVARAJ. Evaluation of in vitro antioxidant activities and antiproliferative activity of green microalgae, Desmococcus olivaceous and Chlorococcum humicola. J. Algal Biomass Utln., 2 (3): 82- 93, 2011.

UTEX. Disponível em: http://www.sbs.utexas.edu/utex/. Acessado em 13.fev.2013.

YAMAGUCHI M, OGAWA T, MURAMOTO K, KAMIO Y, JIMBO M KAMIYA H. Isolation and characterization of mannanbinding lectin from the freshwater cyanobacterium (bluegreen algae) Microcystis viridis. Biochem Biophys Res Comm, 265:703-708, 1999. 